Relations industrielles

Industrial Relations

\title{
Canadian Labour Economics, by Stephen G. Peitchinis, Toronto, McGraw-Hill, 1970, 491 pp.
}

\section{Bernard Brody}

Volume 25, numéro 3, 1970

URI : https://id.erudit.org/iderudit/028163ar

DOI : https://doi.org/10.7202/028163ar

Aller au sommaire du numéro

Éditeur(s)

Département des relations industrielles de l'Université Laval

ISSN

0034-379X (imprimé)

1703-8138 (numérique)

Découvrir la revue

Citer ce compte rendu

Brody, B. (1970). Compte rendu de [Canadian Labour Economics, by Stephen G. Peitchinis, Toronto, McGraw-Hill, 1970, 491 pp.] Relations industrielles /

Industrial Relations, 25(3), 622-623. https://doi.org/10.7202/028163ar

Tous droits réservés @ C Département des relations industrielles de l'Universite Laval, 1970
Ce document est protégé par la loi sur le droit d'auteur. L’utilisation des services d'Érudit (y compris la reproduction) est assujettie à sa politique d'utilisation que vous pouvez consulter en ligne.

https://apropos.erudit.org/fr/usagers/politique-dutilisation/ 
tionner tous les problèmes au sein de l'entreprise et que la première démarche à effectuer dans cette voie, est de reconnaître la priorité aux « relations industrielles ».

L'intérêt de cet ouvrage repose sur le fait que Marcel Bolle de Bal, tout en contribuant à l'avancement des «relations humaines », réussit à décrire le cadre dans lequel ce mouvement se développe.

Jean-Louis LANGEVIN

Canadian Labour Economics, by Shephen G. Peitchinis, Toronto, McGraw-Hill, 1970, $491 \mathrm{pp}$.

At last we have a good, well-rounded labour economics text written specifically for Canadian students. While it is true that theory knows no nationality, there are aspects of the discipline whose importance varies considerably from country to country. Though U.S. research is very useful to help discover the behavior of key Canadian variables and to seek out the causal factors, the plain fact is that our economies are quite different. (I brush aside the thorny problem of distinguishing two cultural identities.) Why shouldn't we have our own texts?

Peitchinis has, fortunately, recognized some of the Canadian peculuarities. His emphasis in labour supply on immigration is a welcome innovation as is his discussion on seasonal unemployment. Wage parity and U.S. patternsetting are of great importance in some Canadian industries. They are irrelevant for the Americans and thus for American textbooks.

It is like a breath of clean, fresh, Spring air that we recognize Canadian source references, Canadian institutions, and the Canadian historical experience. This book is an improvement - more than just the conventional revision over Peitchinis' 1965 text. The latter gave the impression of a series of disjointed articles thrown together in a hurry. It was also more superficial than the new one.

The Phillips Curve discussion is timely, but limited. Given that the book is dated 1970, we should have expected some material on the important Prices and Incomes Commission, organized in
1969. Also, since Peitchinis has used the Isoquant technique for production, one wodners why he did not expose the Indifference curve aparatus - the income/leisure choice - for the determination of individual labour supply. This would, in addition, have permitted a section on the effects of income transfers (and the negative income tax) on supply. I think the issue of income security is sufficiently important in Canada now to merit inclusion in a book dealing with employment, wages, mobility and labour force participation.

The «Concept of the Labour Market», «The Economic and Social Significance of Unemployment》, and «The Meaning of Full Employment 》 are truly excellent pieces. Here again, however, one gets the feeling that the author has stopped too early. Concerning the « Full Employment 》 section, James Tobin's article («On Improving the Economic Status of the Negro ») on «tight full employment $\gg$ (and, incidentally, one of the early Negative Income Tax schemes) is on the reading list of every respectable labour economics course. Some mention of tight full employment or at least the article should have been included as reference.

One of the noticable omissions is the subject of the Minimum Wage. Surely this is a realistic and exer-present enough interference with market forces to have merited a few paragraphs and some diagrams. The orthodox, static, partial treatment of the effects of the minimum wage simply state that this social measure will cause unemployment. There is some room for a real-world, dynamic analysis integrating some offsetting effetcs from a rising demand for labour emanating from a situation of rising incomes.

The section on mobility is extensive and well-written.

Though the Ostry part of the wellknown Woods and Ostry text (Labour Policy and Labour Economics in Canada) is probably more penetrating than some sections of Canadian Labour Economics, it is handicapped by a limited discussion on the theory of the labour market and by the fact that it is now slightly dated (it is currently being revised). Anton's text (Wages and Productivity, 1969) is exciting and useful, but rather restricted to the unionized labour force. 
The traditional text on Labour Economics is divided roughly evenly between labour institutions and the market for labour services. Peitchinis' work is one of the rare instances dealing exclusively with the latter. Although one should not neglect unionism and the government influence on the labour market, the discipline has perhaps become broad enough to usefully permit such division of labour.

\section{Bernard BRODY}

Compulsory Arbitration in Australia, by J. E. Isaac, Study no 4, Task Force on Labour Relations, Ottawa, Privy Council Office, 1970, $84 \mathrm{pp}$.

Dans la série Task Force on Labour Relations, l'étude no 4 mérite une attention particulière. Il s'agit d'une analyse du système d'arbitrage obligatoire qui existe en Australie depuis au-delà de deux tiers de siècle. Elle est d'un professeur de l'université Monash, le professeur J. E. Isaac.

Cette étude est particulièrement d'actualité présentement à la suite de l'élargissement considérable qu'a connu chez nous le droit de grève et les répercussions auxquelles il a donné lieu.

L'Auteur décrit d'abord les caractéristiques fondamentales de la législation du travail en Australie en ce qui a trait à la négociation collective et au règlement des conflits industriels.

Comme le Canada, l'Australie est une confédération politique, ce qui a une incidence sur la législation du travail. A ce propos, qu'il suffise de noter que ic gouvernemeiti central assume en pratique une compétence plus étendue que les Etats.

La législation du travail en Australie est caractérisée principalement par l'existence de tribunaux autonomes qui fixent les taux de salaires, les heures de travail et les autres conditions de travail. En cette matière, les tribunaux jouent un double rôle. Ils agissent comme organismes de conciliation et comme tribinaux d'arbitrage dont les décisions sont obligatoires. Mais il leur appartient aussi de trancher les conflits d'interprétation qui peuvent s'élever entre les parties concernant l'interprétation des textes de conventions collectives et des senten- ces arbitrales ainsi que les cas de congédiement, de mutation, etc...

L'objet de l'arbitrage obligatoire ne vise pas à remplacer la négociation collective, mais uniquement à rendre les grèves inutiles et à en réduire le nombre et la durée. Ceci ne signifie pas que le droit de grève soit entièrement supprimé. La législation varie considérablement d'un Etat à l'autre. En règle générale, plus l'Etat est industrialisé, plus il y a ouverture à la grève. Mais, dans ces derniers cas, le droit de grève n'est acquis qu'après la tenue d'un vote au scrutin secret des travailleurs intéressés. Evidemment, la grève, là où elle est permise, se fait contre les décisions des tribunaux d'arbitrage. Les tribunaux d'arbitrage sont autorisés en outre à y mettre fin, à ordonner le retour au travail sous peine de la suppression de l'enregistrement des syndicats. Quant aux lock-out, ils sont à peu près inexistants.

On peut se demander ici quels résultats a donnés ce système de l'arbitrage obligatoire. Si l'on en juge par l'étude du professeur Isaac, ceux-ci seraient excellents. Un tableau comparatif qu'il a insiré dans son travail sur le nombre de jours-homme perdus par les grèves, entre 1952 et 1963 , permet de voir qu'il était de 7.376 jours dans les mines de charbon, de 6.780 dans l'industrie de l'arrimage et de 0.137 dans les autres activités. Quant aux jours-homme perdus par salarié impliqué dans les grèves, le nombre en était en moyenne au Canada de 1956 à 1965 de 11.0 à 25.3 jours de grève par les travailleurs en grève, et de 1.2 à 2.0 jours en Australie. Et dans le Québec, donc! Plus de 29 jours en 1968. Pour les quatre dernières années citées, le nombre de jours perdus n'a pas dépassé 1.7. On ne peut pas pour autant dire que l'Australie soit un pays sous-développé, puisque le produit national brut par habitant était de $\$ 1,730$. par année, alors qu'il était de $\$ 1,940$. au Canada. On peut aussi ajouter que le système australien donne même un meilleur résultat que le système suédois si vanté où le nombre de jours-homme perdus a augmenté sensiblement au cours des dernières années.

L'auteur conclut son travail en notant qu'il faut porter au crédit du système australien quatre avantages : $1^{\circ}$ il a permis de mettre sur pied un mécanisme qui permet de règler rapidement les conflits industriels; $2^{\circ}$ la généralisation 